الهام رزمى و همكاران

\title{
Immobilization of Laccase Enzyme on Silica-Coated Iron Oxide Nanoparticles and Comparison of Stability and Activity of Free and Immobilized Laccase
}

\author{
Elham Razmi ${ }^{1}$, Ahmad Jonidi Jafari ${ }^{2,3}$, Ali Esrafili ${ }^{3,4}$, Emad Dehghanifard ${ }^{5,6}$, Roshanak Rezaei Kalantari ${ }^{2,3^{*}}$
}

1. M.Sc, Department of Environmental Health Engineering, School of Public Health, Iran University of Medical Sciences, Tehran, Iran

2. Professor, Department of Environmental Health Engineering, School of Public Health, Iran University of Medical Sciences, Tehran, Iran

3. Research Center for Environmental Health Technology, Iran University of Medical Sciences, Tehran, Iran

4. Associate Professor, Department of Environmental Health Engineering, School of Public Health, Iran University of Medical Sciences, Tehran, Iran

5. Assistant Professor, Department of Environmental Health Engineering, School of Public Health, Alborz University of Medical Sciences, Karaj, Iran

6. Research Center for Health, Safety and Environment (RCHSE), Alborz University of Medical Sciences, Karaj, Iran

*E-mail: rezaei.r@iums.ac.ir

Received: 26 Jun 2018 ; Accepted: 25 Sep 2018

ABSTRACT
Background: Laccase enzyme is capable of oxidizing many resistant and non-biodegradable
environmental pollutants, so it has been studied frequently in recent years and is widely used in
biodegradation of contaminants. Despite its abundant applicability, due to its short life span, non-
recovery, thermal instability and instability in organic environments, its widespread use is very limited.
The present study aimed to increase the stability of laccase by immobilizing it on silica coated iron
oxide nanoparticles.
Materials and Methods: $\mathrm{Fe}_{3} \mathrm{O}_{4}$ nanoparticles were synthesized based on the co-precipitation
method and after coating with silica, their surface was modified by amine groups. The enzyme was
then immobilized by covalent binding using glutaraldehyde. Specifications of synthesized
nanoparticles and immobilized enzyme were investigated using X-ray diffraction (XRD), Field
Emission Scanning Electron Microscopy (FESEM), and Energy-dispersive X-ray spectroscopy
(EDX).
Results: Results of successful laccase immobilization on nanoparticles showed that laccase
immobilization significantly increased storage and thermal stability, maintaining activity in a wider
range of temperature and pH than free laccase.
Conclusion: The immobilization of laccase on silica-coated iron oxide nanoparticles can reduce the
barriers and challenges of various enzymes by increasing its efficiency and stability.
Keywords: Laccase, Immobilization, Silica-coated iron oxide nanoparticles, Enzyme Activity




\title{
تثبيت آنزيم لكاز بر روى نانوذرات اكسيد آهن يوشيده با سيليس و مقايسه يايدارى و فعاليت آنزيم لكاز آزاد و تثبيتشده
}

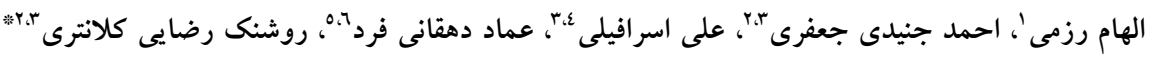 \\ ' دانش آموخته كارشناسى ارشد، گروه مهندسى بهداشت محيط، دانشكده بهداشت، دانشگاه علوم يزشكى ايران، تهران، ايران

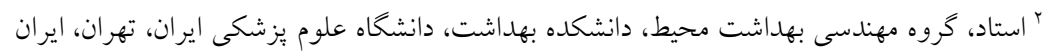

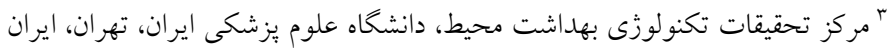

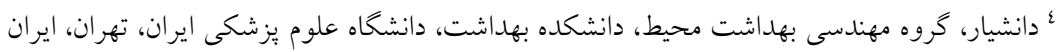 \\ • استاديار، كروه مهندسى بهداشت محيط، دانشكده بهداشت، دانشخاه علوم يزشكى البرز، كرج، ايران

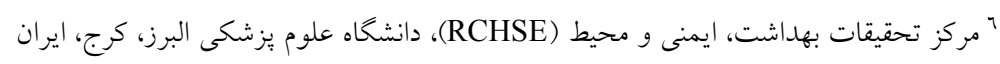

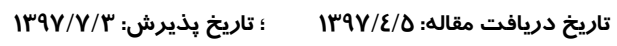

\section{جكيد}

زمينه و هدف : آنزيم لكاز قادر به اكسيد كردن بسيارى از آلايندهاى زيست محيطى مقاوم و غيرقابل تجزيه بيولوزيكى مى باشد، بـهـ

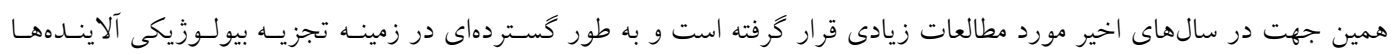

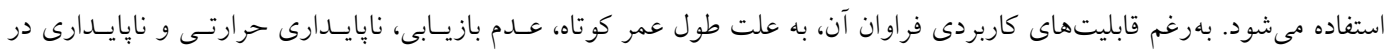

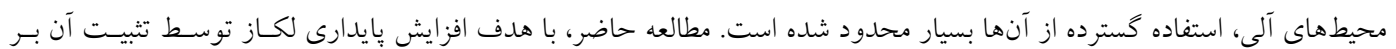
روى نانوذرات اكسيد آهن يوششدار شده با سيليس انجام بذيرفت.

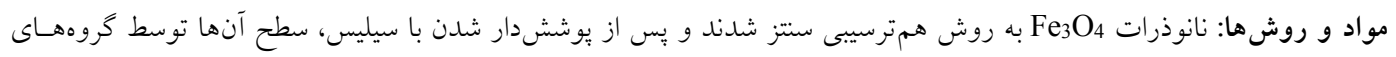

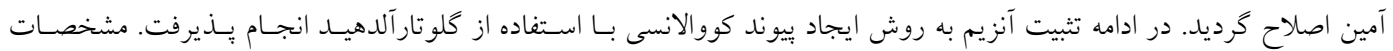

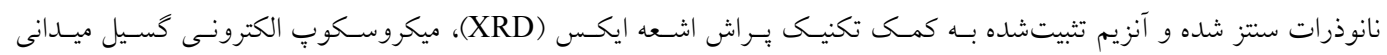

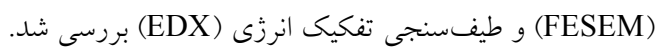

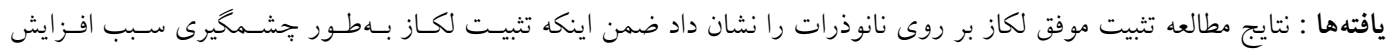

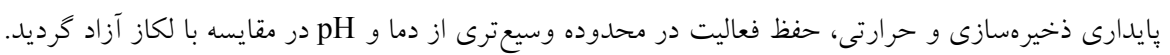

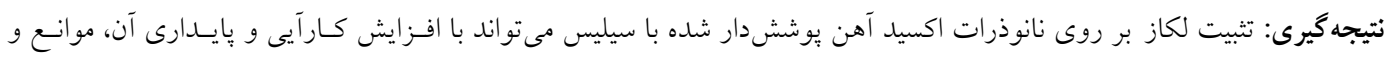
جالشهاى بيش روى كاربردهاى متنوع اين آنزيم را كاهش دهد. كلمات كليدى: لكاز، تثبيت، نانوذرات اكسيد آهن يوششدار شده با سيليس، فعاليت آنزيم 
استفاده مجلد از آنزيم و كاهش هزينههاى كـاربردى شـود. در

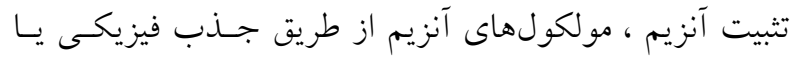

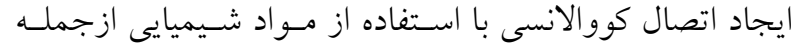
كلوتارآلدهيد بر روى بسترى با سطح زيـاد متصـل شــده و يـا

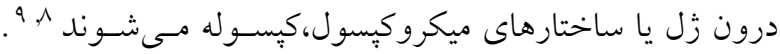
تاكنون مطالعات بسيار گسترداى در مورد تثبيت لكاز بر روى بسـترهاى مختلــف نظيـر كـربن فعـال، سـيليكا، كائولينيــت،

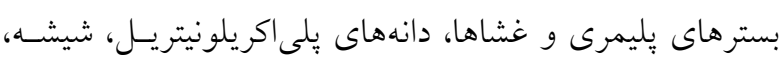

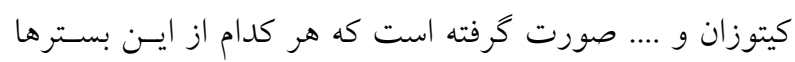

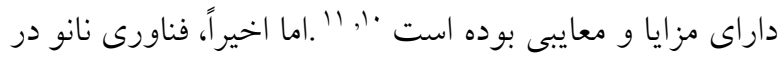

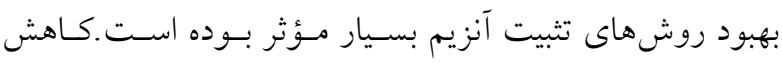

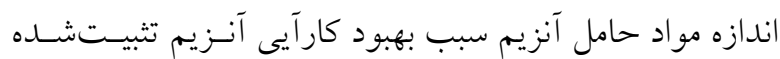

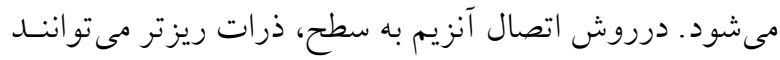

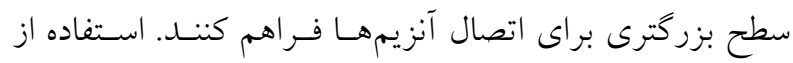

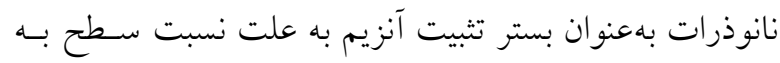

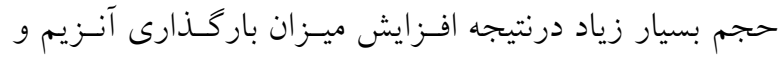

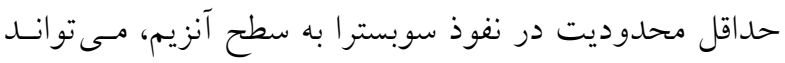

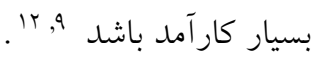
يكى از مشكلات استفاده از آنزيمها ، جداسازى و بازيابى

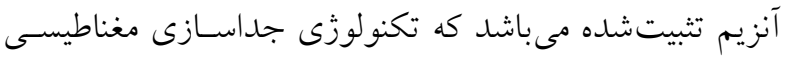
يك تكنولوزى نويدبخش مى باشد. جداسازى و بازيابى آنـزيم

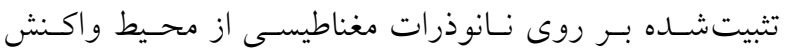

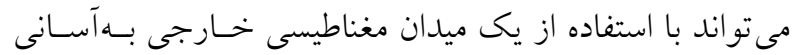

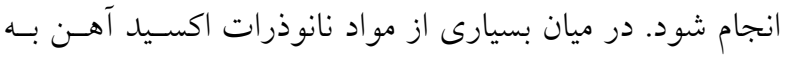

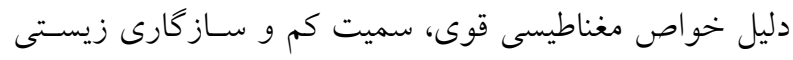

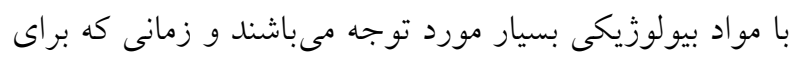

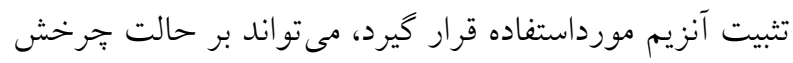

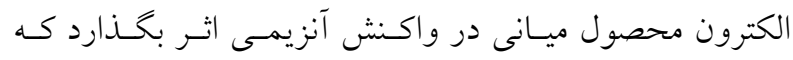

\section{مقدمه}

لكازها (بنزندىال: اكسيزن اكسيدوردو كتاز، EC 1.10.3.2) آنزيمهاى برون سلولى و جند مسى هستند كه متعلق بـهـ يــ

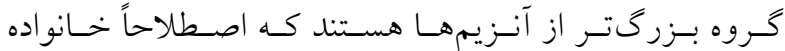
اكسيدازهاى آبى خند مسى ناميده مىشود. نـام لكـاز از محـل

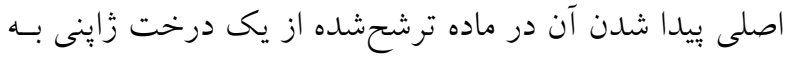

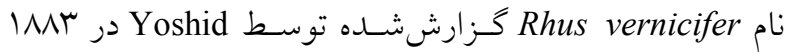
بركرفتهشده است. لكازها البته در كَياهان ديخر و نيز حشـرات و باكترىها نيز يافت مىشوند، اما بهطور گسترده در كونهاى

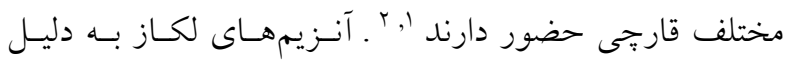

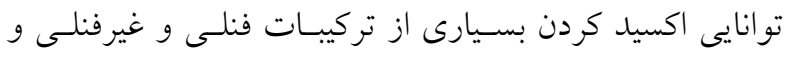

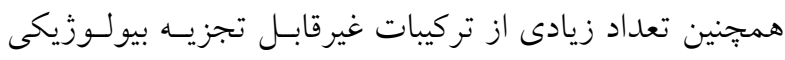

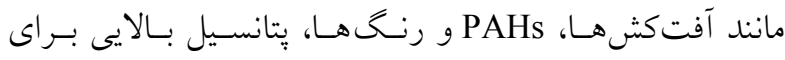
كاربرد در تصفيه فاضلابها و پِاكسازى خاكهاى آلـوده بـهـ

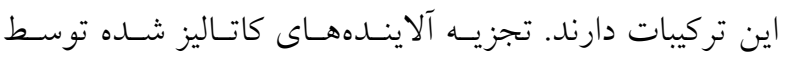

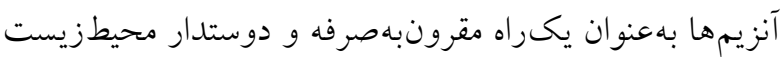

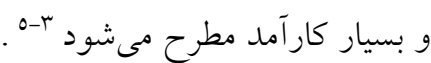

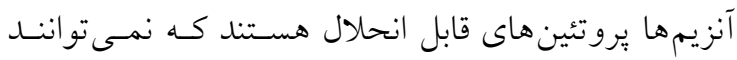

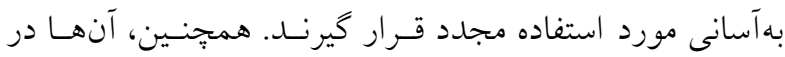

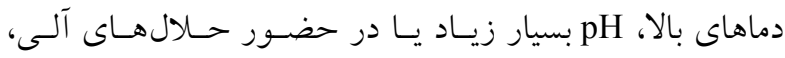

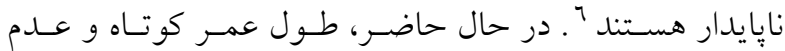
بازيابى آنزيمها استفاده از آنها را محدود كرده است. با با توجسهـ به اهميتى كه آنزيم لكاز در بيوتكنولوزى و كاربردهاى فـراوان

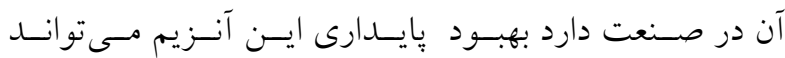

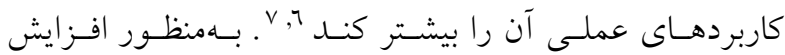

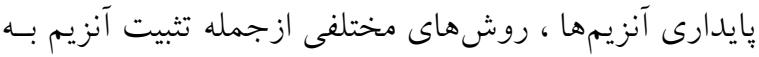

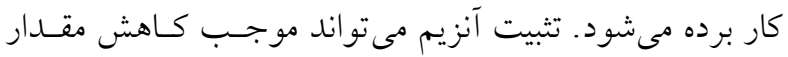
مصرفى آنزيمها، افزايش طول عمر راكتورهاى آنزيمى، قابليت 
آنـزيم لكـاز حاصـل از قـارج Trametes versicolor

2,2-Azinobis (3-ethylbenzothiazoline-6-sulfonate) كه به عنوان مدياتور در مطالعه حاضر استفاده كرديد (ABTS) و 3-aminopropyltrimethoxysilane(APTES) به منظور عامل

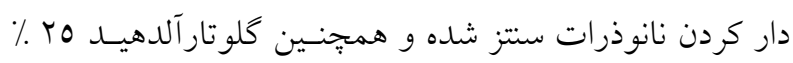
بهنوان عامل ايجادكننده بيوند كووالانسى ميان بستر و وآنـزيم

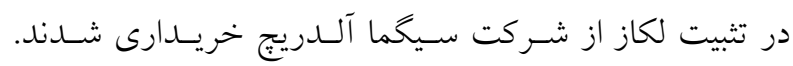
براى سنتز نانوذرات اكسيد آهن $\mathrm{FeCl}_{3} .6 \mathrm{H}_{2} \mathrm{O}$ و $\mathrm{FeCl}_{2} .4 \mathrm{H}_{2} \mathrm{O}$ Tetraethyl orthosilicate(TEOS) ،

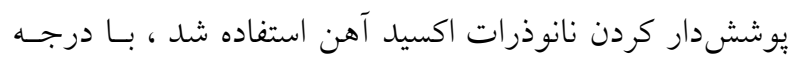
خلوص آزمايشگاهى از شركت مرك تهيه كرديد.

\section{سنتز نانوذرات اكسيد آهن مغناطيسى(Fe3} بهمنظور سنتز نانوذرات كلريــد آهـن 7 آب (

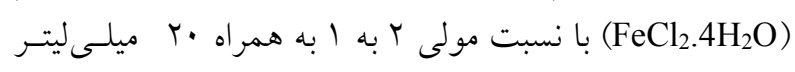

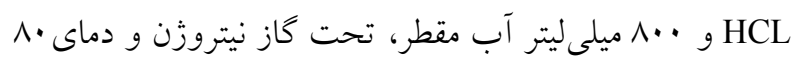

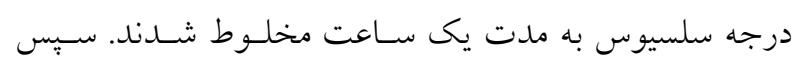
•ع اميلى ليتر آمونياك (

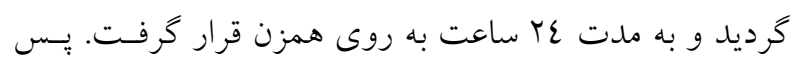

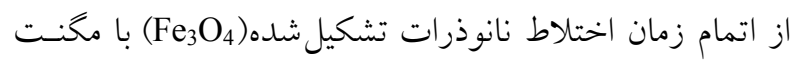

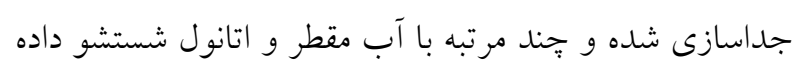

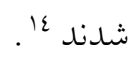

يوششدار كردن نانوذرات Fe33 با سيليس

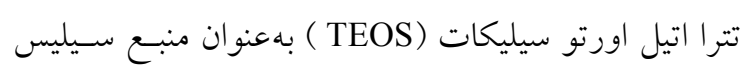

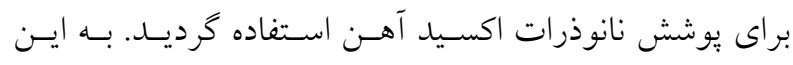

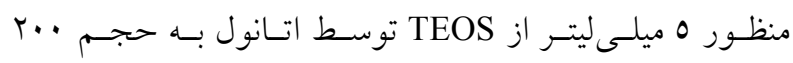

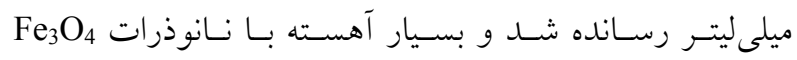

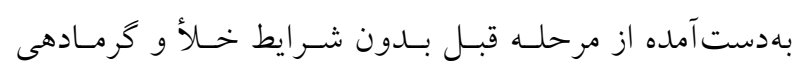

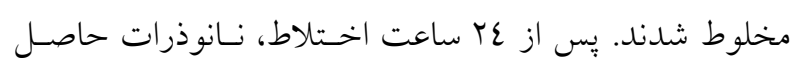

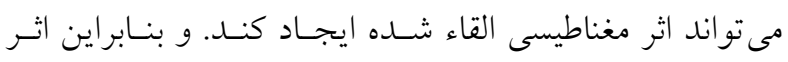

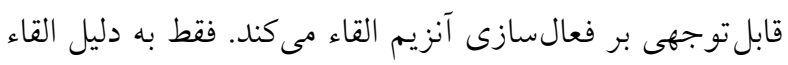

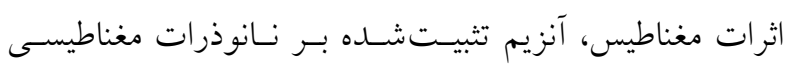

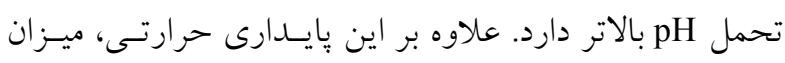

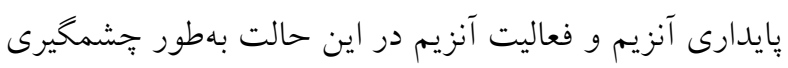

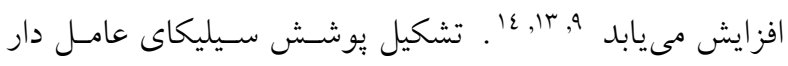

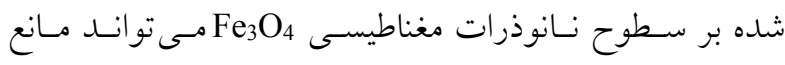

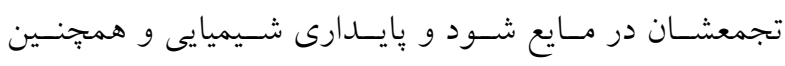

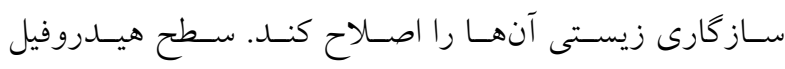

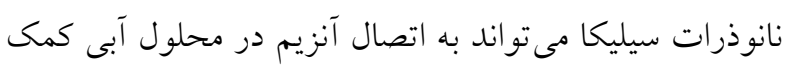

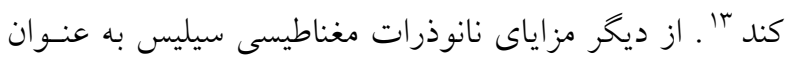

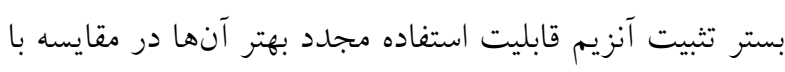

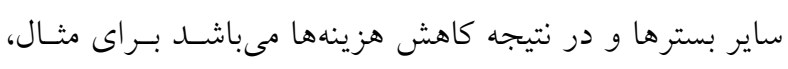

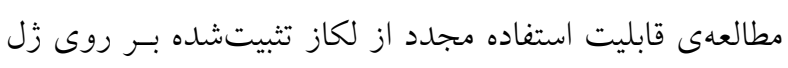

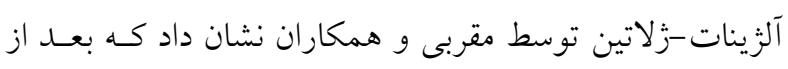

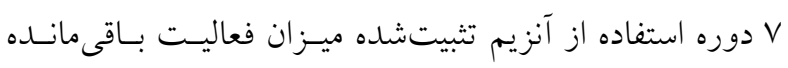

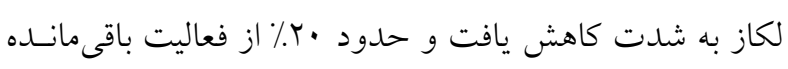

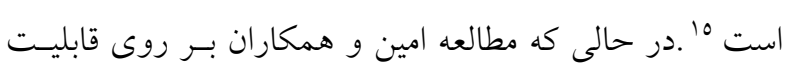

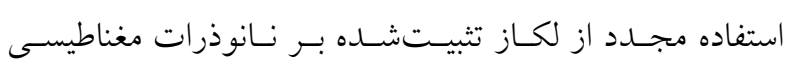
سيليس نشان داد ميزان فعاليت باقىمانده بعد از لإن بار استفاده

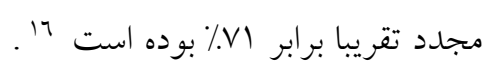

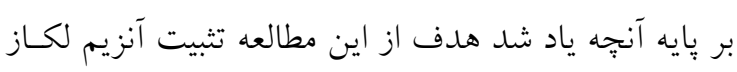

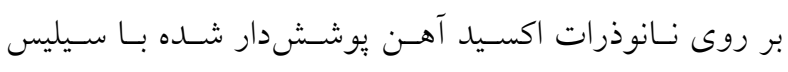

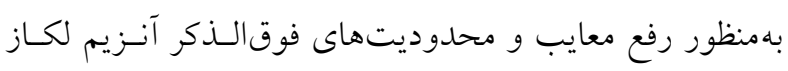

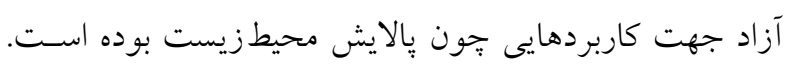

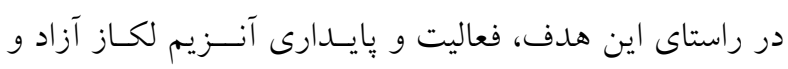
تثبيتشده بررسى شد.

\section{مواد و روشها} مواد شيميايى 
تثييت لكاز بر روى نانوذرات اكسيد آهن بِوشيده با سيليس و مقايسه پايدارى و فعاليت كاتاليستى لكاز آزاد و تثبيتشده

فسفات در دماى ع درجه سلسيوس ذخيره شدند ז', 11.

\section{تعيين مشخصات نانوذرات سنتزشده}

مشخصات نانوذرات سنتزشـده بـا روشهـاى متـداول در

متون تعيسين كرديـــ. بـهـهنظور مطالعـهى سـاختار كريستالى نانوذرات سنتز شده از تكنيك ٍِراش اشـعه ايكسس (XRD) بـا

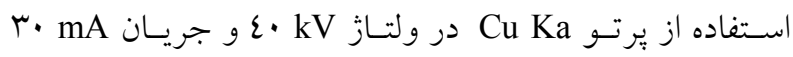
بهره كرفته شد. مورفولوزى نانوذرات سنتزشده قبـل و بعـد از

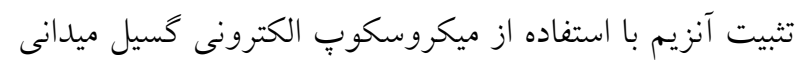
مـــ MIRA3TESCAN-XMU مشــاهده شـــ (FESEM) همجنين تركيب عناصر موجود در نانوذرات سنتز شده قبـل و بعد از تثبيت لكاز با اسـتفاده از طيـفســنجى تفكيـى انـرزى تعيين كرديد. (EDX)

\section{سنجش فعاليت آنزيم آزاد و تثبيتشه}

فعاليت كاتاليستى آنزيم لكاز آزاد و تثبيتشده با استفاده از

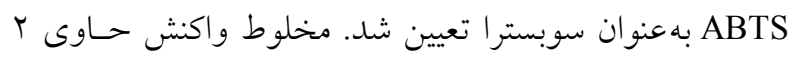
ميلى مولار ABTS و مقدار مناسب لكاز آزاد يا تثبيتشده در بافر فسفات در pH برابر ه آماده گرديد و در دمـاى هזدرجسه سلسيوس با سـرعت •10 دور در دقيقـه بـه مـــت · ل دقيقـه انكوباسيون شد. يس از اتمام زمان انكوباسـيون، نـانوذرات بـاــا

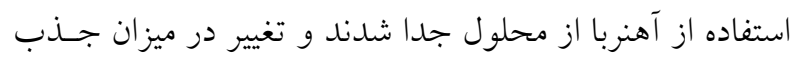

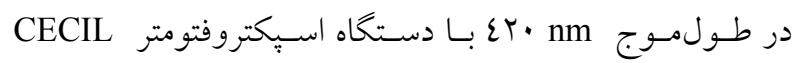
UV/VIS

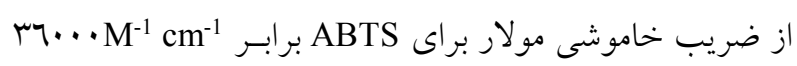

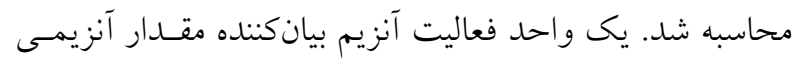

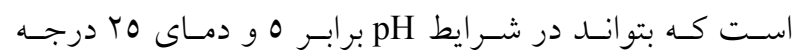
سلسيوس يك ميكرومول از سوبسترا را در يك دقيقـه اكسـيد

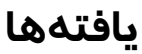

جند مرتبه با آب مقطر و اتانول شستشو داده $\left(\mathrm{Fe}_{3} \mathrm{O}_{4} @ \mathrm{SiO}_{2}\right)$

شدند 12

آمين دار كردن نانوذرات

بهمنظور اصلاح سطح نانوذرات با كروههاى آمين، محلـول

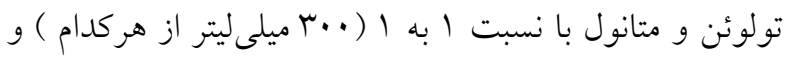

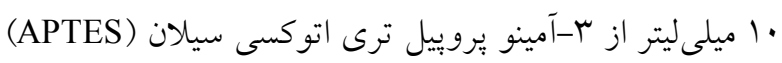

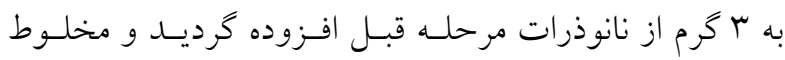

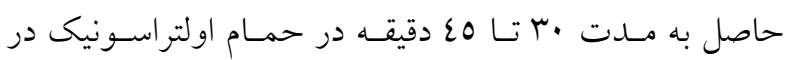

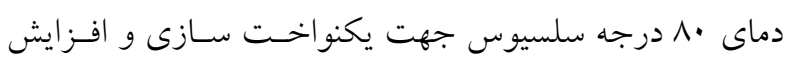

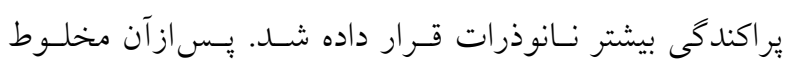

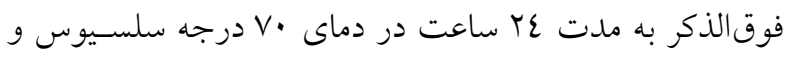

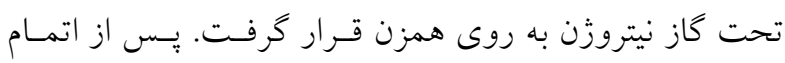
زمان اختلاط نـانوذرات

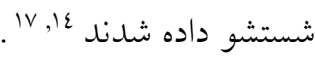

\section{تثبيت آنزيم لكاز بر روى نـانوذرات - Fe304@SiO} $\mathrm{NH}_{2}$ تثبيت آنزيم با استفاده از محلـول كلوتار آلدهيــ بـهــــوان

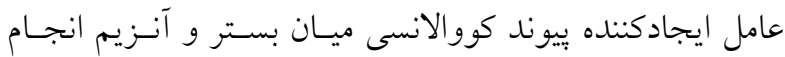

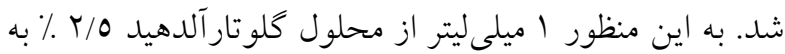

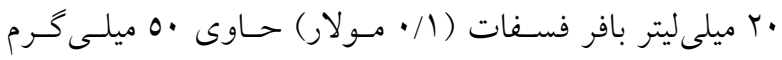
نانوذرات Fe

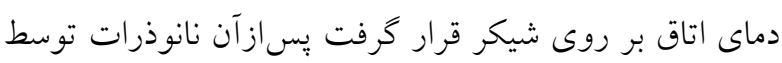

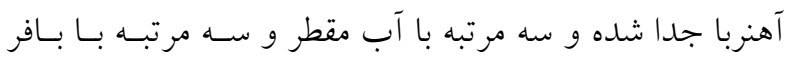
فسفات بهصورت يكدرميان شستشو داده شد تا كلو تار آلدهيد

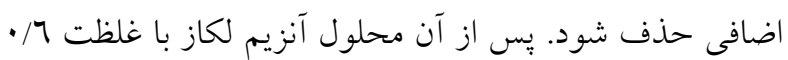

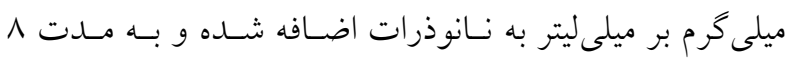

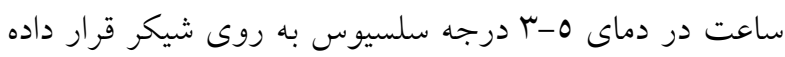

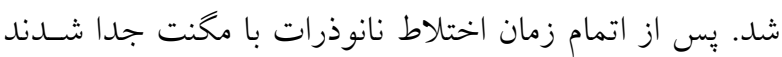

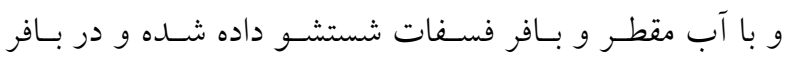


تثبيت آنزيم ارائه شدهاند كه نشان دهنده مورفولوزى نانوذرات

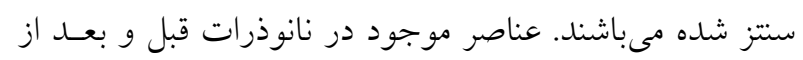

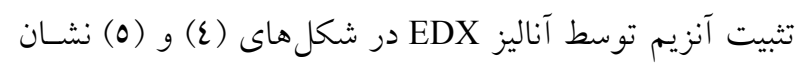
داده شدهاند.

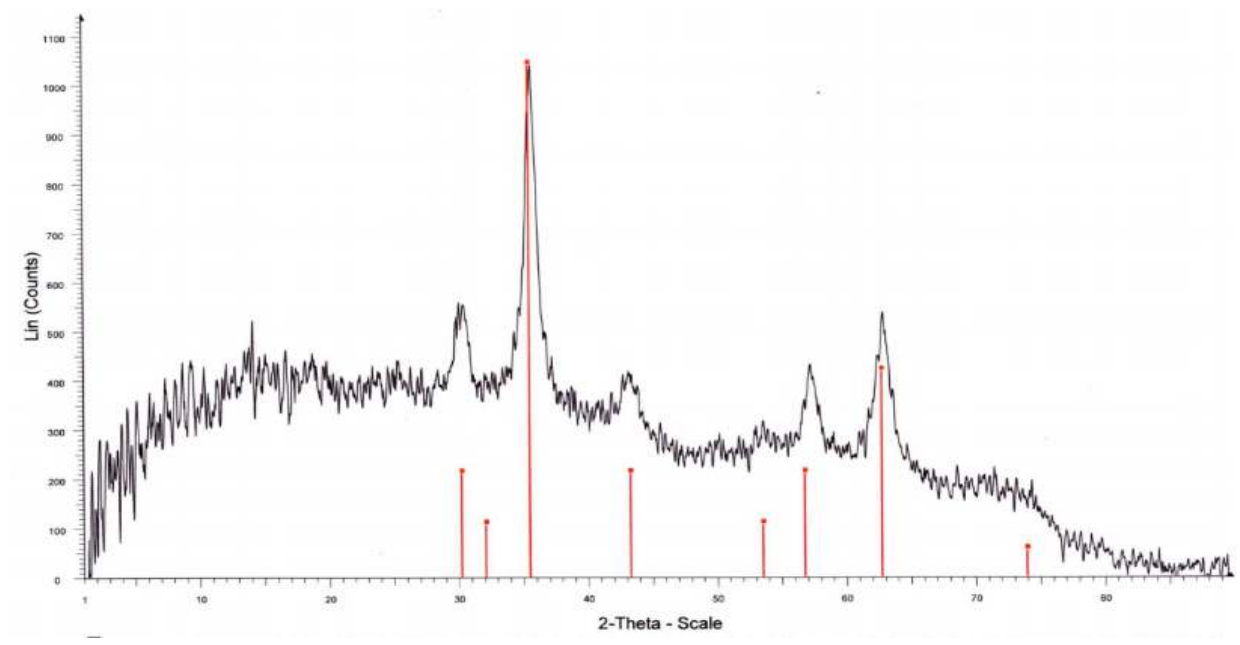

شكل ا: الكوى طيف يراش اشعه ايكس نانوذرات
مشخصات نانوذرات سنتزشده الكوى طيف يراش اشعه ايكس نـانوذرات

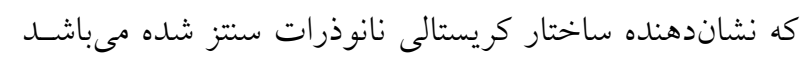

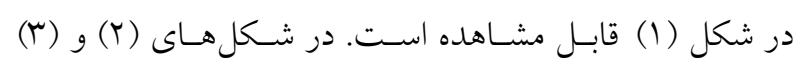

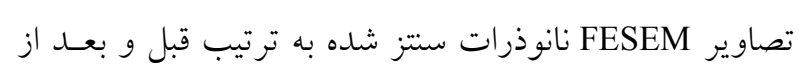

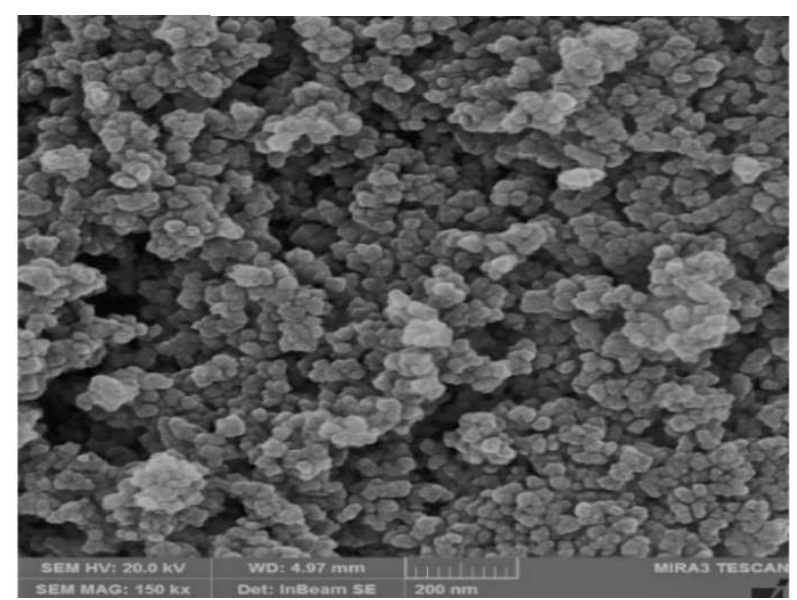

شكل بّ: تصوير FESEM نانوذرات Fe

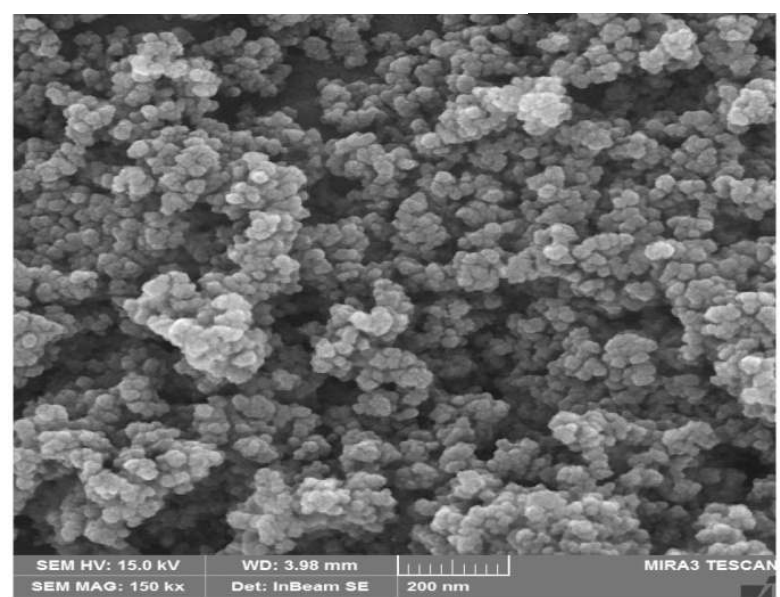

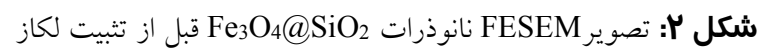




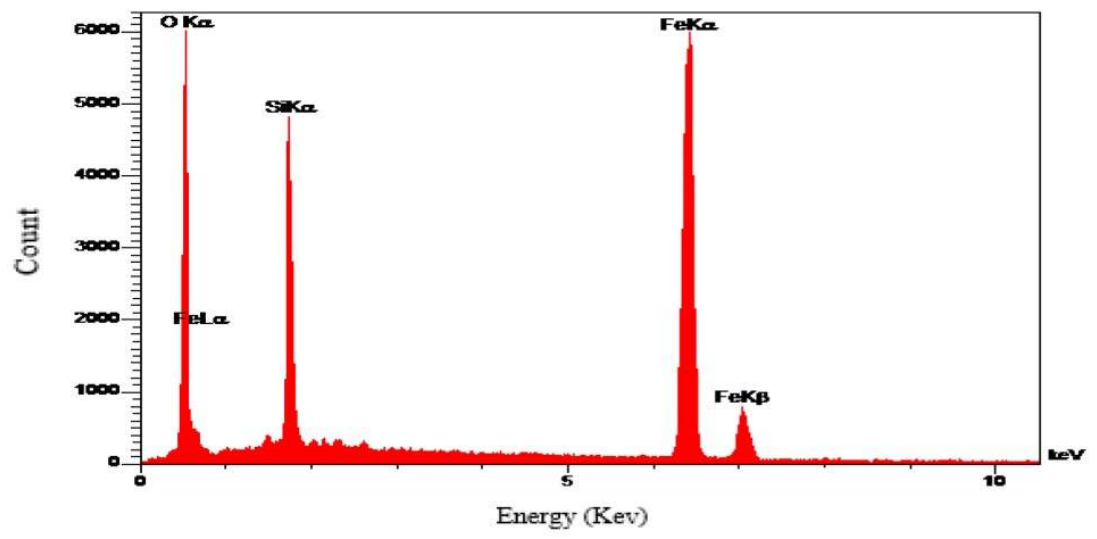

شكل ع: طيف سنجى تفكيك انرزى قبل از تثبيت لكاز

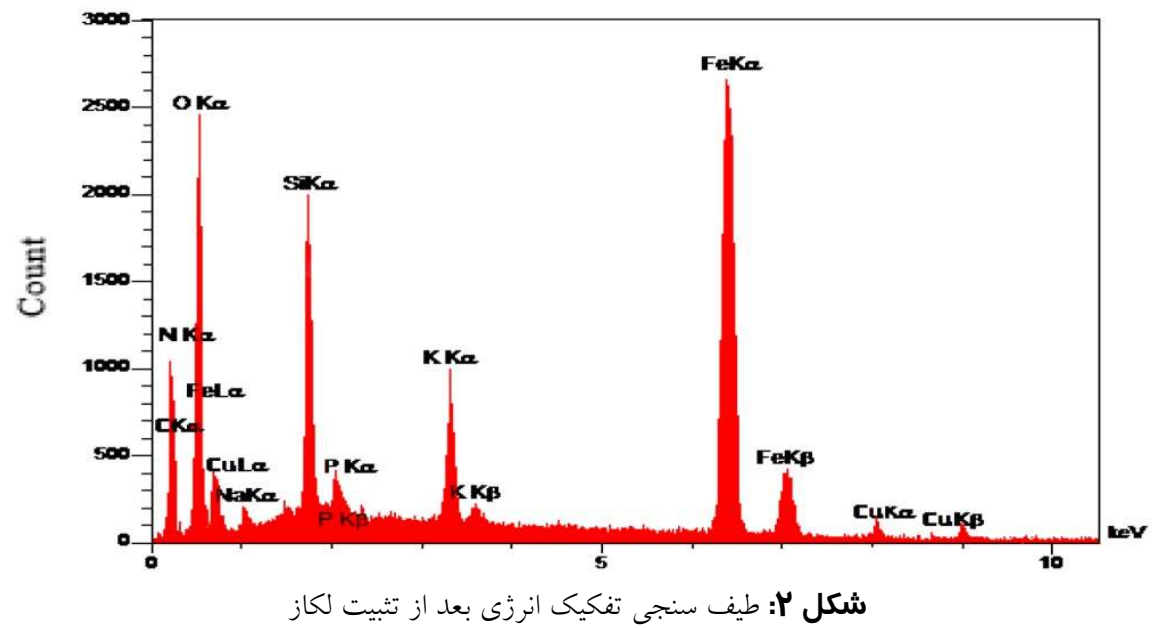

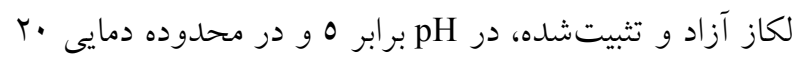

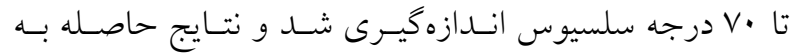

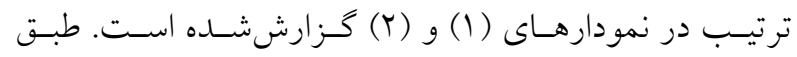
نمودارهاى مذكور بيشينه فعاليت آنزيم آزاد و تثبيـتشــده بـهـ

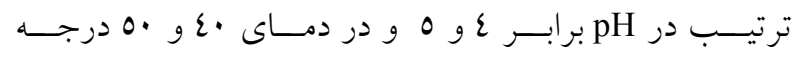
سلسيوس حاصل گرديد.
تـأثير pH و دمــا بـر روى فعاليـت آنـزيم آزاد و تثبيت شده

فعاليت كاتاليستى آنزيمها بهشدت تحـت تـأثير pH و دمـا است به همين جهـت رونــ تغييـر فعاليـت آنـزيم در شـرايط مختلف pH و دما ارزيابى شده اسـت. تـأثير تغييـرات pH بـر pH فعاليت آنزيم، در دماى Y T درجه سلسيوس و در محدوده

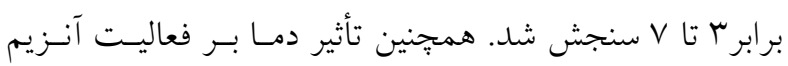



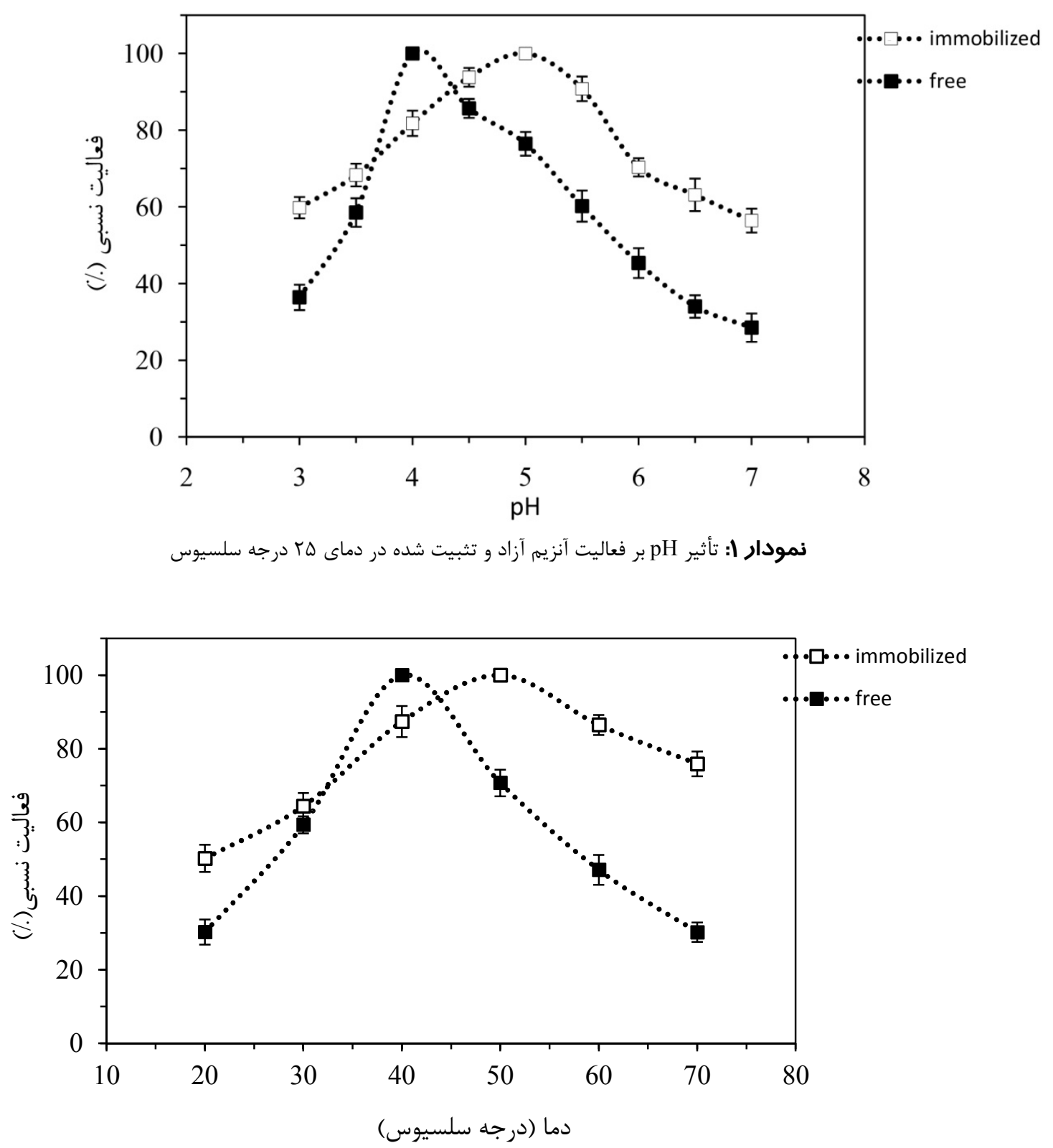

نمودار ץ: تأثير دما بر فعاليت آنزيم آزاد و تثبيت شده در pH برابر 0 


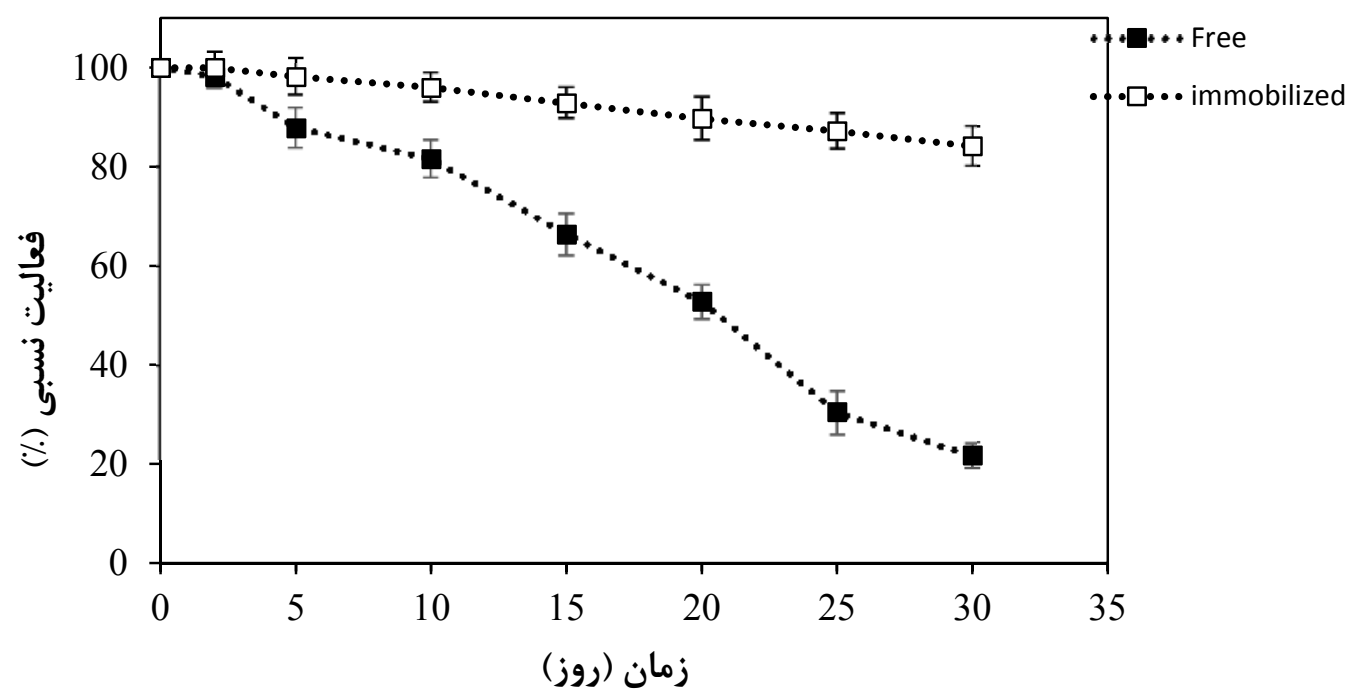

نمودار سا: ثبات ذخيره سازى آنزيم آزاد و تثبيت شده

سنجيده شد. فعاليـت بـاقى مانــده بـر اسـاس درصــ فعاليـت باقى مانده به اوليه گزارش شده است. بـر اسـاس ايسن نمـودار

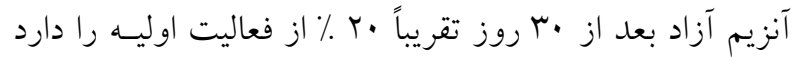
درحالى كه آنزيم تثبيتشده بـيش از •^ ٪ از فعاليـت اوليسه را حفظ نموده است.
يايدارى ذخيرهسازى آنزيم آزاد و تثبيتشده نمودار (r)، نتايج ثبات ذخيرهسـازى در مـدت •ب روز را

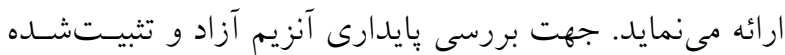
در طى دوره ذخيرهسـازى در بـافر فسـفات ( M

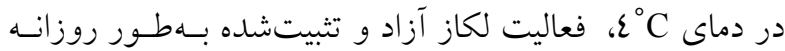
موردسنجش قرار گرفت. بستر حاوى آنزيم تثبيتشده بهطـور روزانه برداشتشده و ميزان فعاليت آن توسط محلـول ABTS

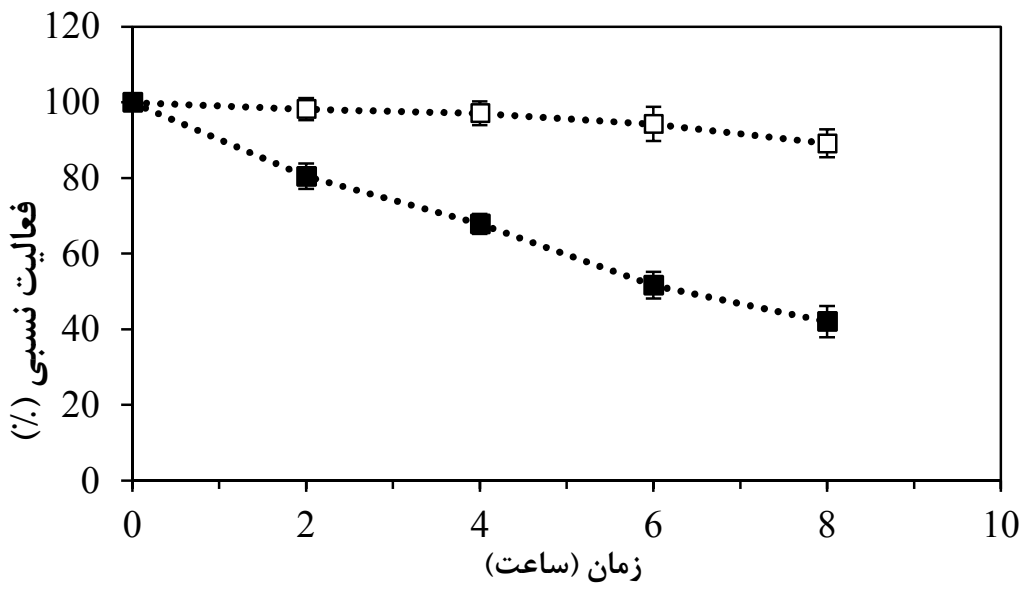

نمودار ع: پايدارى حرارتى آنزيم آزاد و تثبيت شده در دماى •0 درجه سلسيوس و pH برابر 0 در مدت ^ ساعت 
آنزيم تثبيتشده نيز بررسى گرديد. به اين منظور تعداد دفعاتى

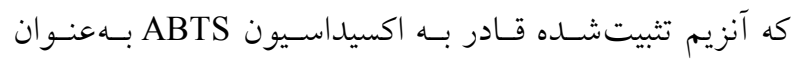

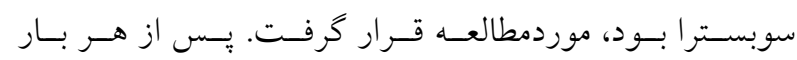

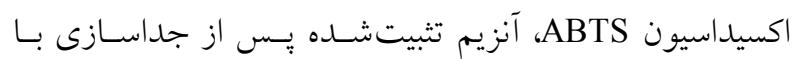

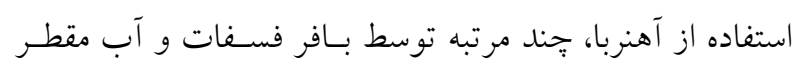
شتشو داده شد و مجدداً در محلول تازه ABTS قرار كرفت.

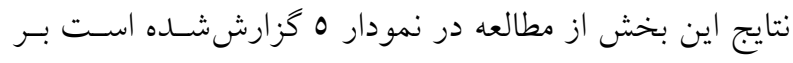

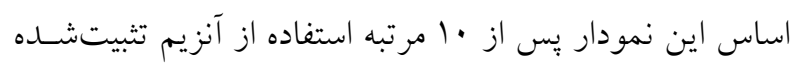

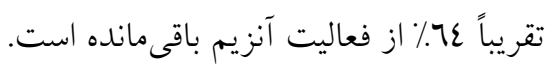

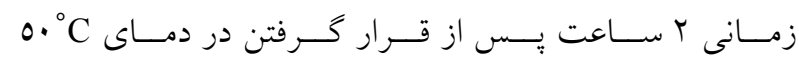

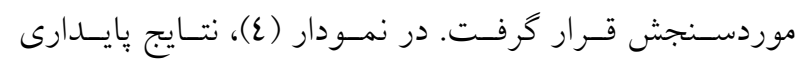
حرارتى آنزيم آزاد و تثبيتشده قابل مشاهده است. طبق نمودودار

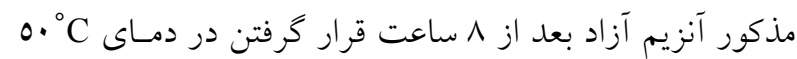

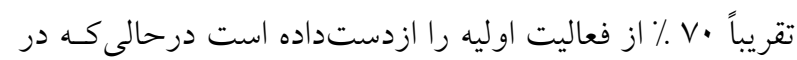

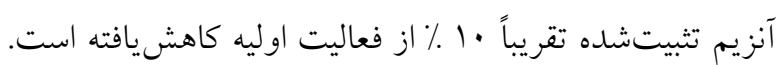

\section{قابليت استفاده مجدد آنزيم تثبيتشده} يكى از مهمترين مزاياى تثبيت آنزيم تو انايى استفاده مجدد

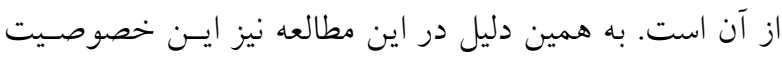

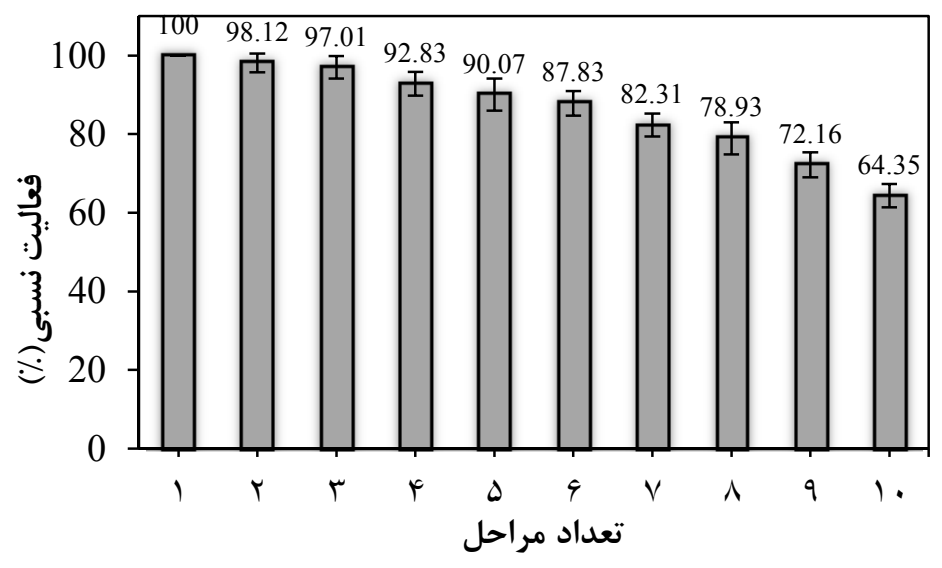

口immobil...

نمودار ठ: قابليت استفاده مجدد آنزيم تثبيت شده

مىباشد ‘r. مر مطالعه Wang و همكاران نيز نتايج آناليز WRD نانوذرات مشـات $\mathrm{Fe}_{3} \mathrm{O}_{4} @ \mathrm{SiO}_{2}$

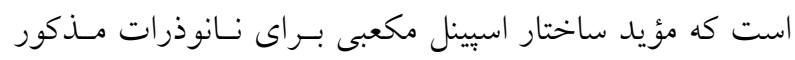

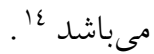
در شـكل (Y) كـهـ تصـوير SEM قبـل از تثبيـت را نشـان مى دهد، مورفولوزى كروى نـانوذرات

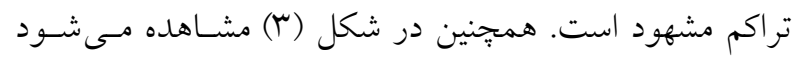

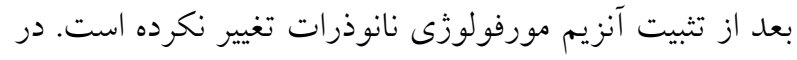

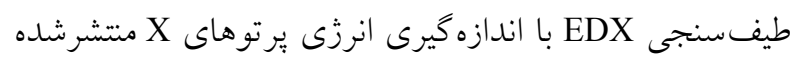

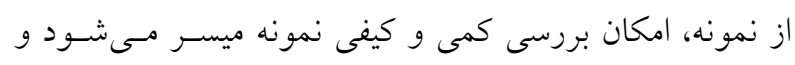

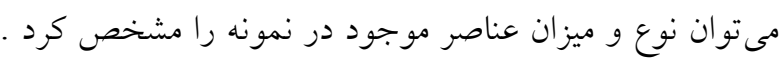

\section{بحث}

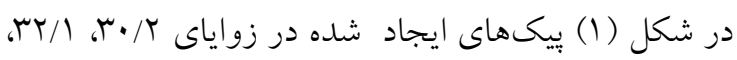
BS EN Tro/N

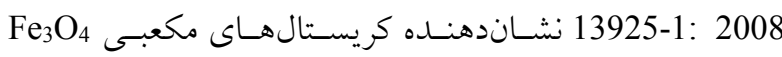
مىباشد. همجنين حداكثر بيكى در زاويه rO/V درجه مشـاهده

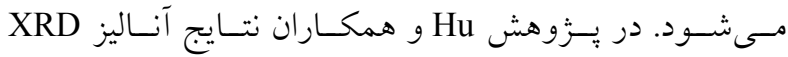
نانوذرات

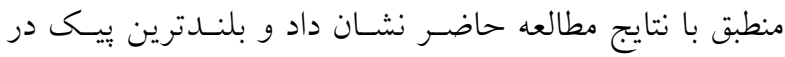

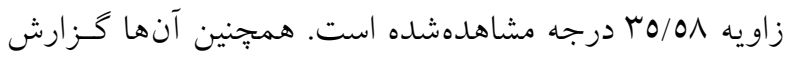

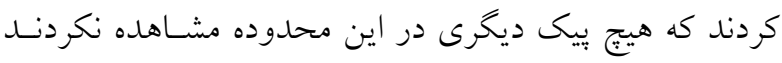

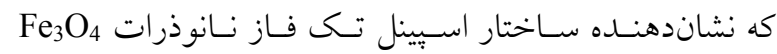


تثييت لكاز بر روى نانوذرات اكسيد آهن بِوشيده با سيليس و مقايسه پايدارى و فعاليت كاتاليستى لكاز آزاد و تثبيتشده

مىنمايد كه مىتواند از دناتوراسيون اسـيدى يـا قليـايى آنـزيم

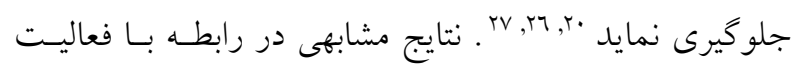

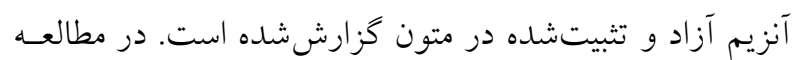

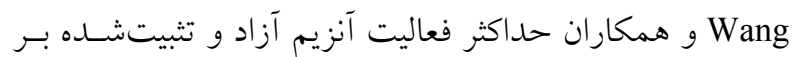
روى نانوذرات مغناطيسى سيليس مزوحفره بـهـ ترتيـب در pH

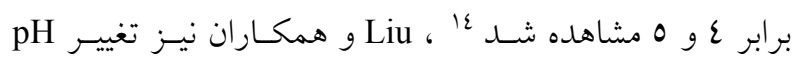

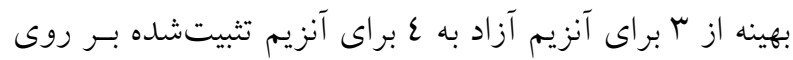
نانوذرات كربن مزوحفره مغناطيسى را كَارش كردند همجنين

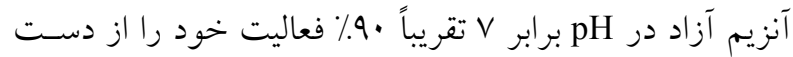

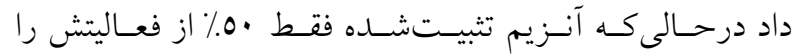

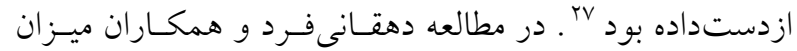
فعاليت لكاز آزاد و تثبيتشده بر روى سـيليكاى متخلخـل در

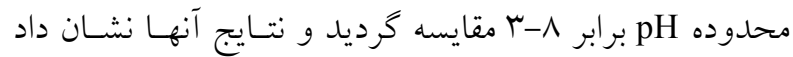

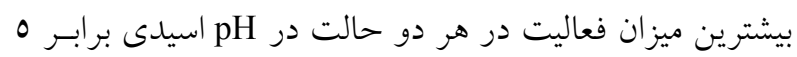

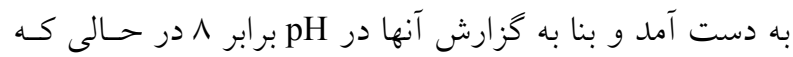

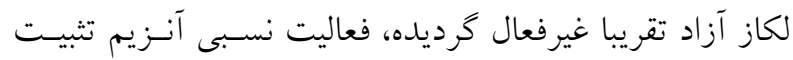

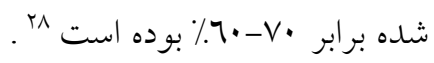

\section{تأثير دما بر فعاليت لكاز آزاد و تثبيت شده}

نمودار (Y) نشان مىدهد كه حلداكثر فعاليـت آنـزيم آزاد و

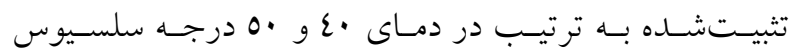

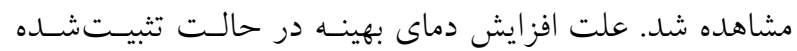

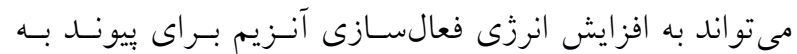
سوبسترا در حالت تثبيتشده نسبت داده شود. علاوه بـر ايسن، كاهش تحرك مولكولى آنزيم تثبيتشده منجر به حفظ فعاليت

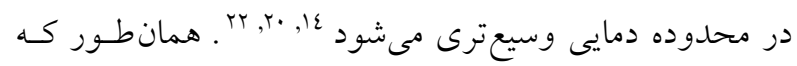

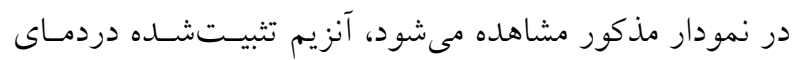

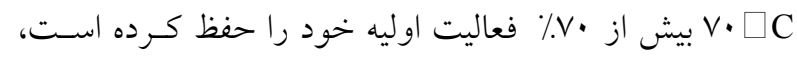

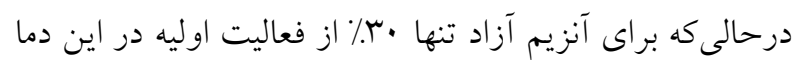

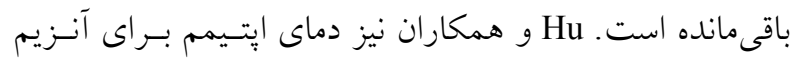

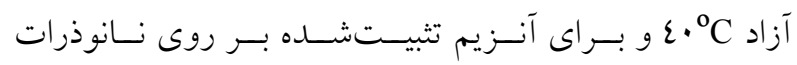

شـكل (ع) وجــود عناصـر آهـن، اكسـيزن و ســيليس را در

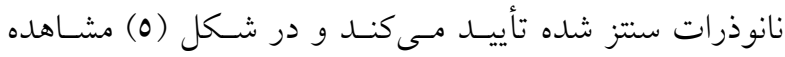
مىشود كه علاوه برَّ عنصر فوقالذكر عناصر نيتـروزن، كربن

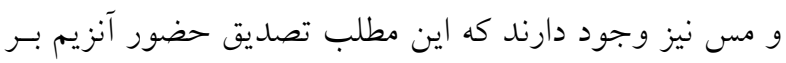
روى نانوذرات حضور عناصر فسفر، يتاسيم و سديم به دليل بافر مورداستفاده مى.باشد .1.

\section{تأثير pH بر فعاليت لكاز آزاد و تثبيتشده}

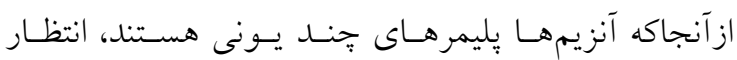

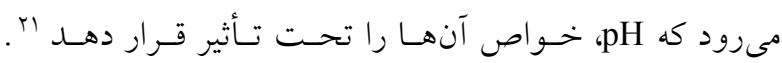

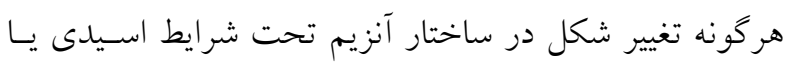

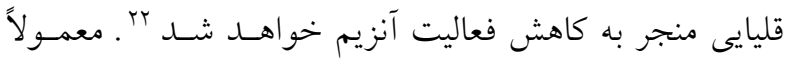
روند تغيير فعاليـت لكـاز در pH هـاى متفـاوت داراى شـكل

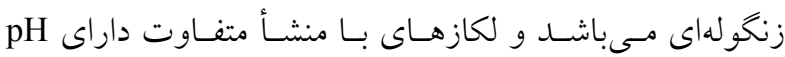
إيتيمم در محدوده |1 ا-1 مىباشند. اما اغلب لكازهاى قـاريى

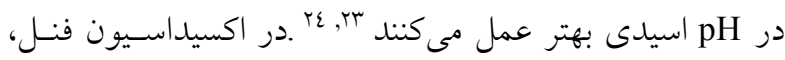
بهينه براى لكاز استخر اجشده از كياهـان، برابـر 9 و وبـراى

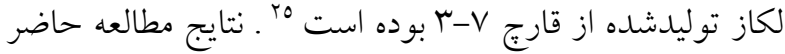

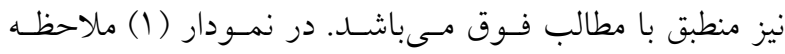

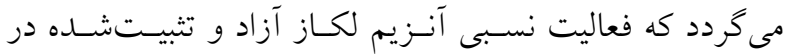
محدوده pH بر ابر بr تا V از شكل زنكو لهاى تبعيت مسى كنــ و

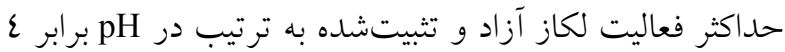
و 0 ، نمايان شـده اسـت. تغييـر pH بهينـه بعـد از تثبيـت بـهـ

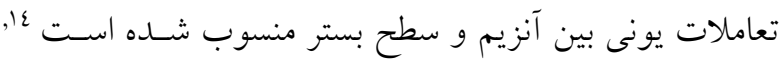

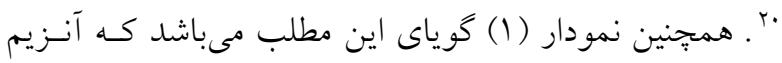

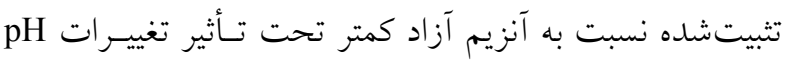

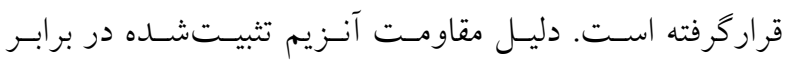

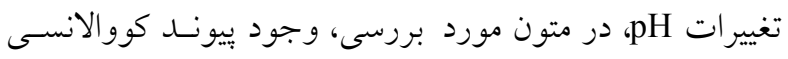

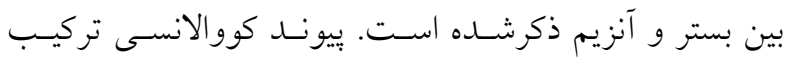

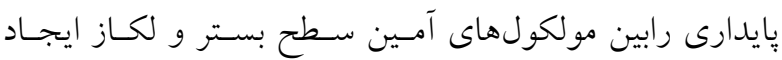


با نتايج يزوهش حاضر مطابقت دارد. Dai و همكـاران جهـت

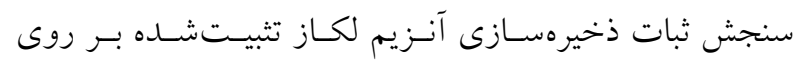

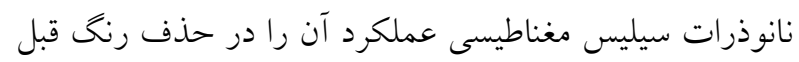

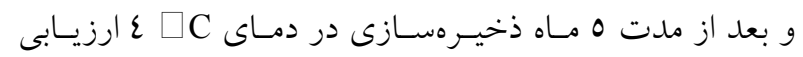

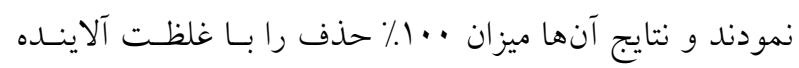

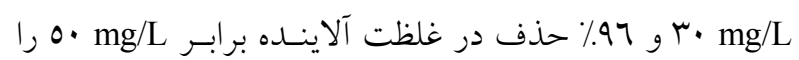

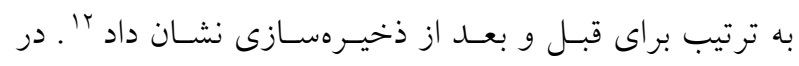

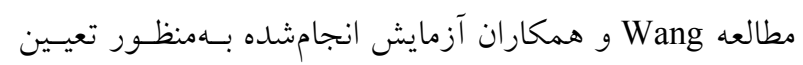

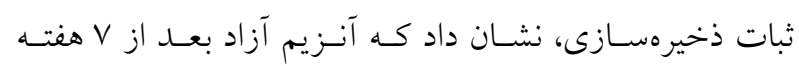
ذخيرهسازى در دماى C

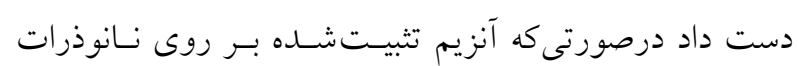

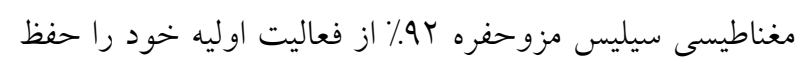

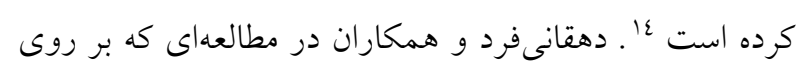
ثبات ذخيرهسازى لكاز تثبيتشده بر سيليكاى متخلخل انجـام

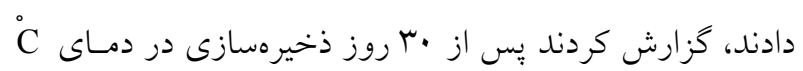

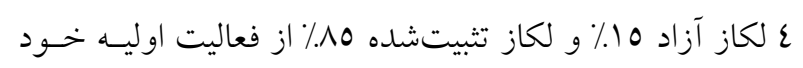
را حفظ نموده استت " ". در مطالعـه امسين و همكـاران لكهاز

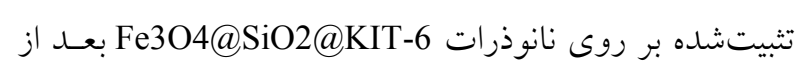

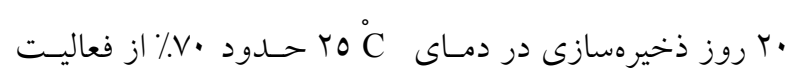

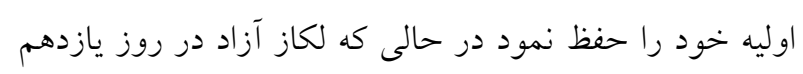

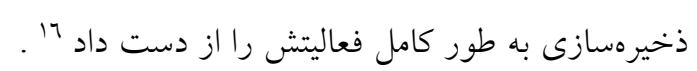

\section{يايدارى حرارتى لكاز آزاد و تثبيتشده}

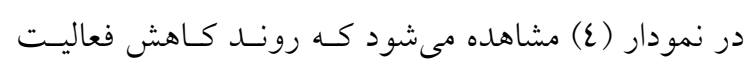

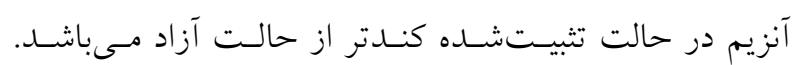
بهورى كه آنزيم تثبيتشده در دماى

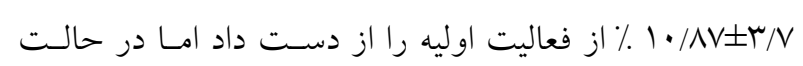

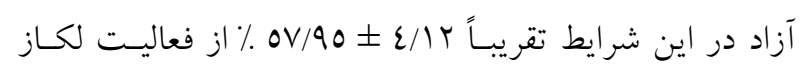
كاهش يافت است. Hu و همكاران كزارش نمودند كه فعاليـت

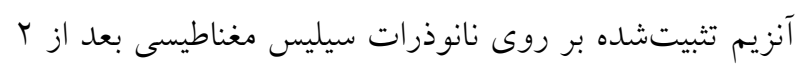

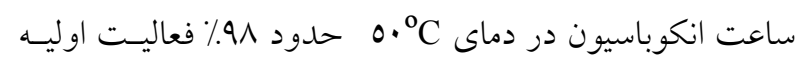

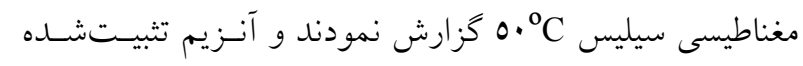

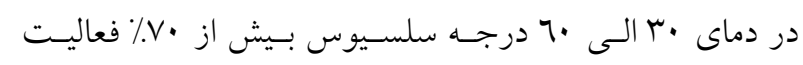

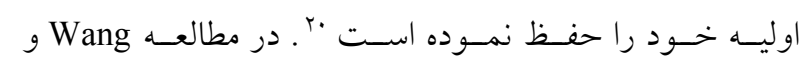

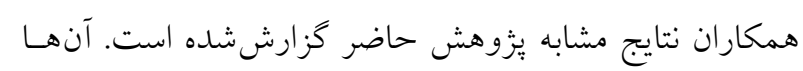

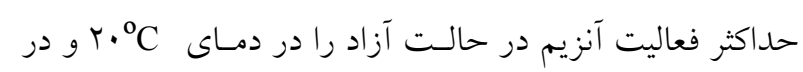

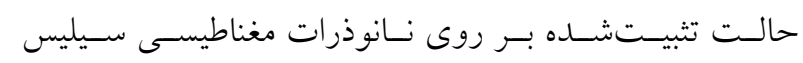
مزوحفره دماى داد كه در دماىC

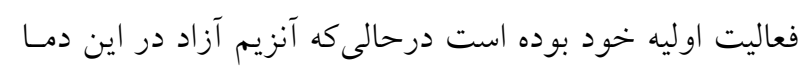

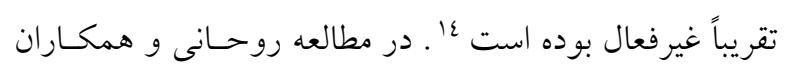

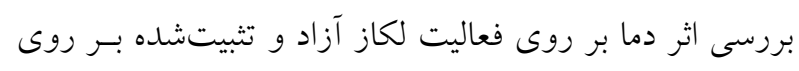

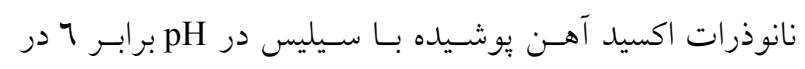

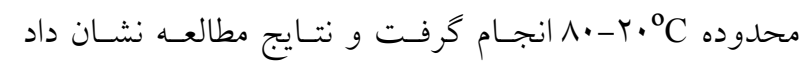

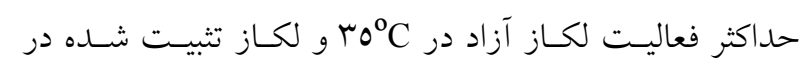
ع بوده درحسالى كـه دمـاى $20^{\circ} \mathrm{C}$

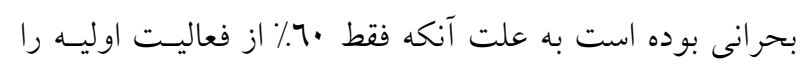

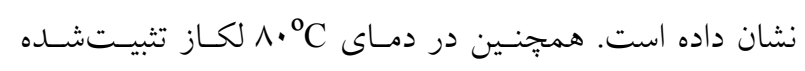

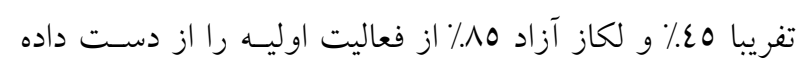

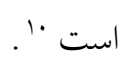

\section{ثبات ذخيرهسازى لكاز آزاد و تثبيتشده}

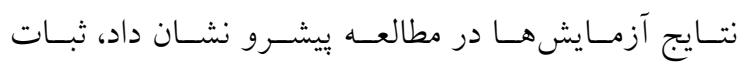

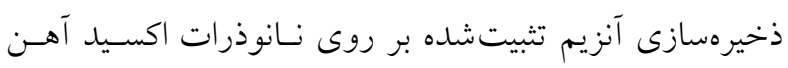

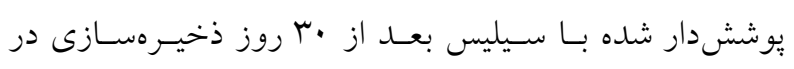

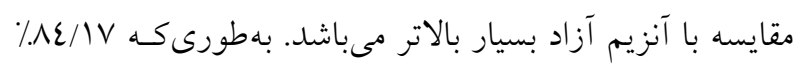

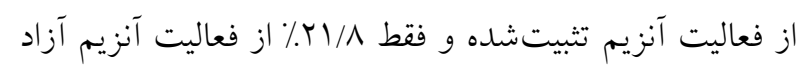

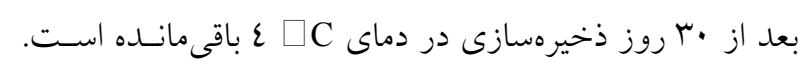

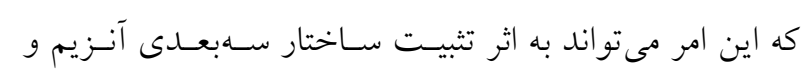

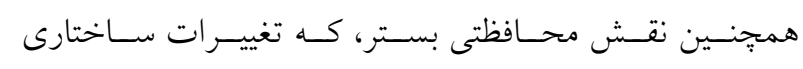

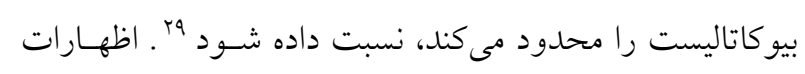

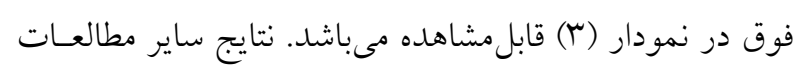


تثييت لكاز بر روى نانوذرات اكسيد آهن بِوشيده با سيليس و مقايسه پايدارى و فعاليت كاتاليستى لكاز آزاد و تثبيتشده

نانوذرات مغناطيسى سـيليس بـا اسـتفاده از ABTS بـهـعنـوان

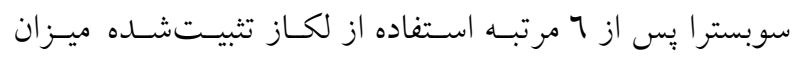

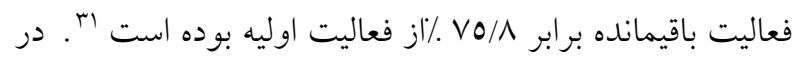
مطالعه dai و همكاران براى ارزيابى قابليت استفاده مجدد لكاز

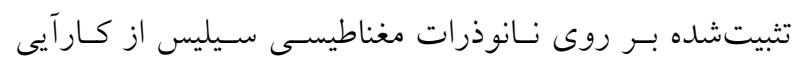

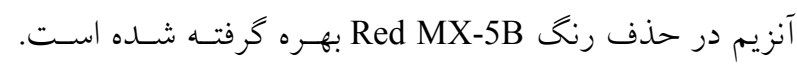

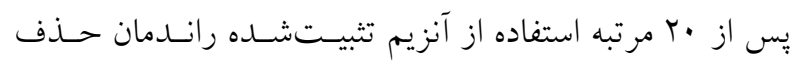

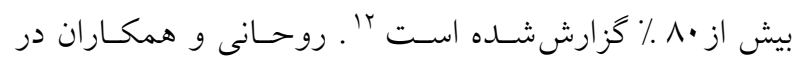
يززوهش خود به منظور مطالعه قابليت اسـتفاده مجــد از لكـاز

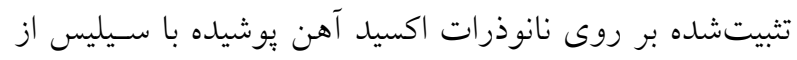

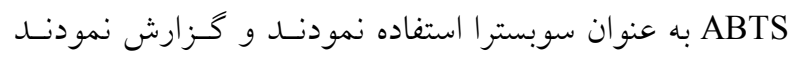

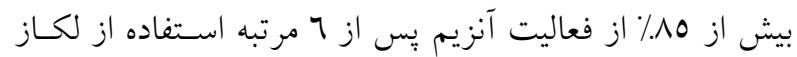

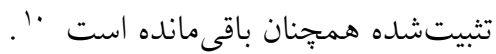

\section{نتيجه گيرى}

طبق يافتهاى به دست آمده از اين يُزوهش تثبيت لكاز بر

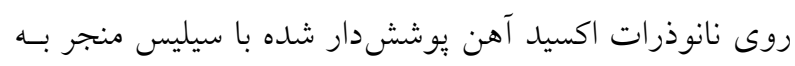

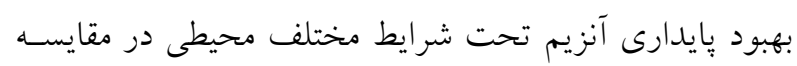

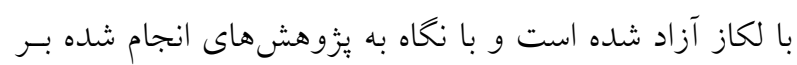

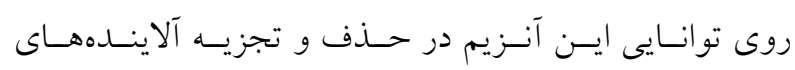

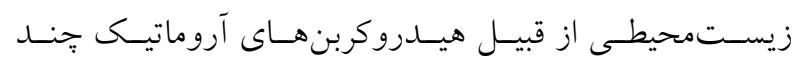

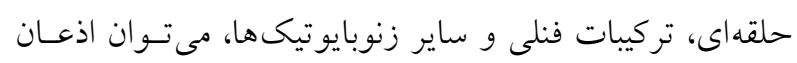

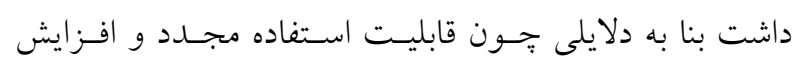

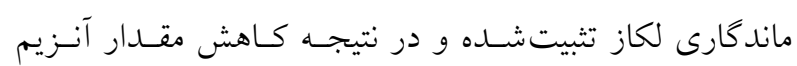

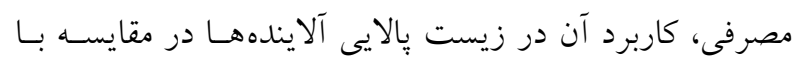

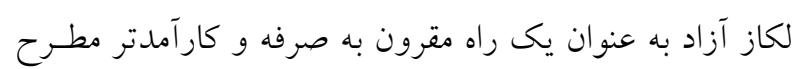

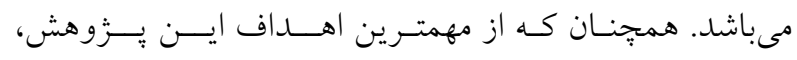

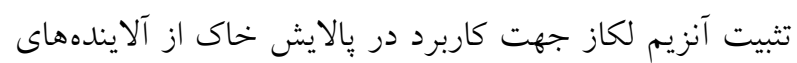

$$
\text { آلى بوده است. }
$$

بوده است درحالى كه آنزيم آزاد حسـود •عـ٪ از فعاليـت اوليسه

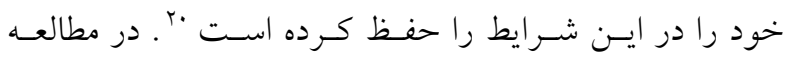

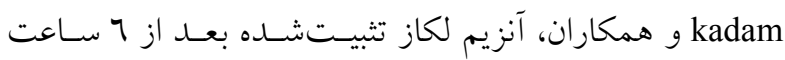

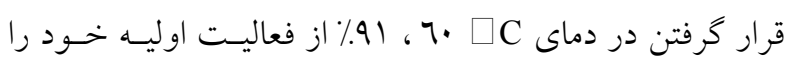

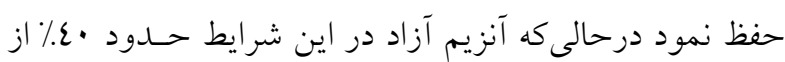

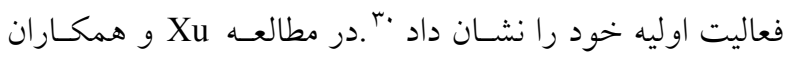

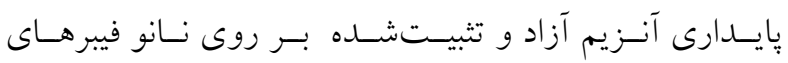

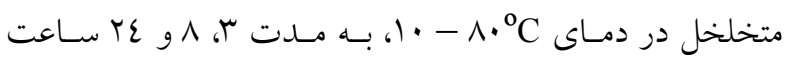
سنجش شده است و نتايج خزارش شده نشاندهنده اين مطلـب

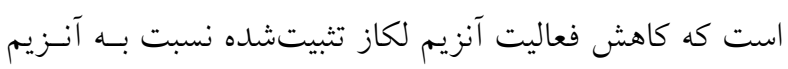

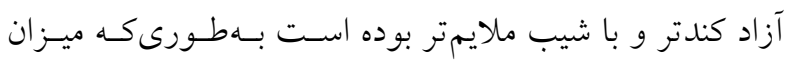

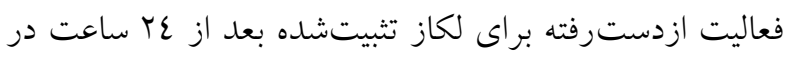

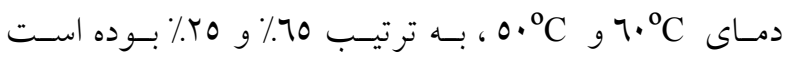

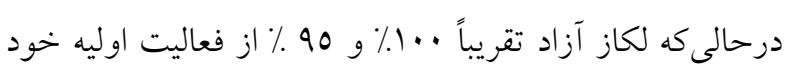

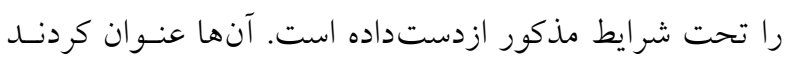

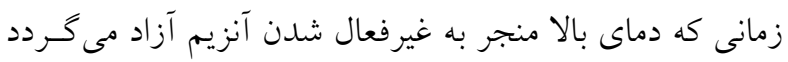

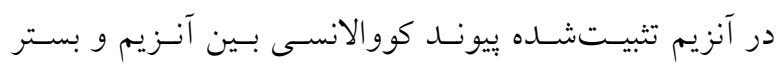

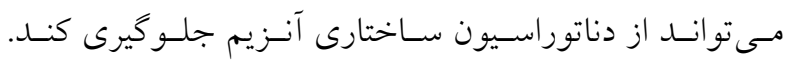

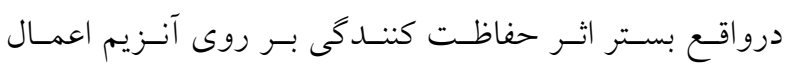

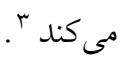

\section{قابليت استفاده مجدد لكاز تثبيتشده}

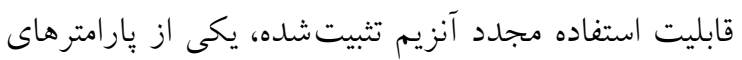

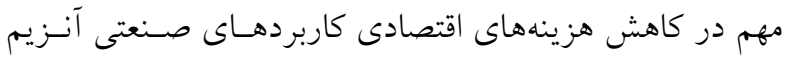

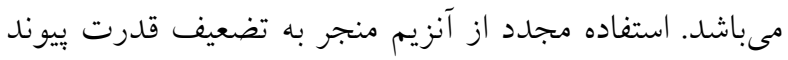

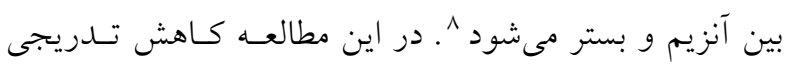
توانيى اكسيداسيون ABTS توسط لكاز تثبيتشده در نمـودار

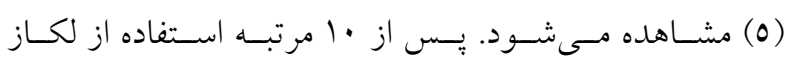

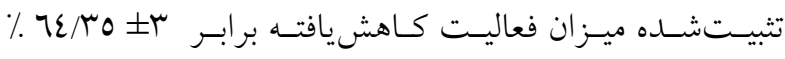

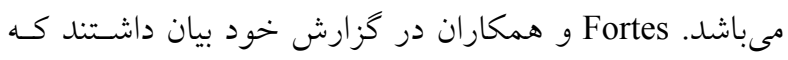

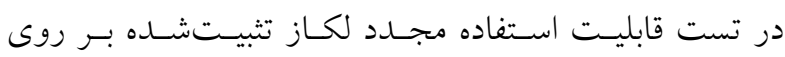




$$
\begin{aligned}
& \text { مهندسى بهداشت محيط مصوب دانشخاه علوم يزشـكى ايسران } \\
& \text { در سال عqrا و به كد •rVOT مى باشد. بدينوسـيله از حسوزه }
\end{aligned}
$$

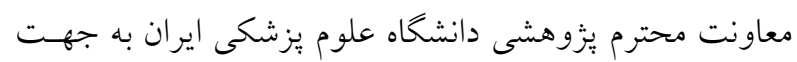

$$
\begin{aligned}
& \text { حمايت مالى طرح تشكر و قدردانى به عمل مى آيد. }
\end{aligned}
$$

\section{References}

1. Polaina J, MacCabe AP. Industrial enzymes: Springer; 2007.

2. Senthivelan T, Kanagaraj J, Panda R. Recent trends in fungal laccase for various industrial applications: an ecofriendly approach-a review. Bioprocess Eng 2016;21(1):19-38.

3. Xu R, Si Y, Wu X, et al. Triclosan removal by laccase immobilized on mesoporous nanofibers: strong adsorption and efficient degradation. Chem Eng J. 2014;255:63-70.

4. Kunamneni A, Plou FJ, Ballesteros A, Alcalde M. Laccases and their applications: a patent review. Recent Pat. Biotechnol 2008;2(1):10-24.

5. Bautista LF, Morales G, Sanz R. Immobilization strategies for laccase from Trametes versicolor on mesostructured silica materials and the application to the degradation of naphthalene. Bioresour. Technol 2010;101(22):8541-8.

6. Datta S, Christena LR, Rajaram YRS. Enzyme immobilization: an overview on techniques and support materials. Biotech 2013;3(1):1-9.

7. Couto SR, Herrera JLT. Industrial and biotechnological applications of laccases: a review. Biotechnol Adv 2006;24(5):500-13.

8. Fernández-Fernández M, Sanromán MÁ, Moldes D. Recent developments and applications of immobilized laccase. Biotechnol Adv 2013;31(8):1808-25.

9. Ahmad R, Sardar M. Enzyme immobilization: an overview on nanoparticles as immobilization matrix. Biochem Anal Biochem 2015;4(2):1.

10. Rouhani S, Rostami A, Salimi A. Preparation and characterization of laccases immobilized on magnetic nanoparticles and their application as a recyclable nanobiocatalyst for the aerobic oxidation of alcohols in the presence of TEMPO. RSC Adv. 2016;6(32):2670918.

11. Dehghanifard E, Jafari AJ, Kalantary RR, et al. Biodegradation of 2, 4-dinitrophenol with laccase immobilized on nano-porous silica beads. Iran J Environ Health Sci Eng 2013;10(1):25.

12. Dai J, Wang $\mathrm{H}$, Chi $\mathrm{H}$, et al. Immobilization of laccase from Pleurotus ostreatus on magnetic separable $\mathrm{SiO} 2$

\section{سياسگزارى}

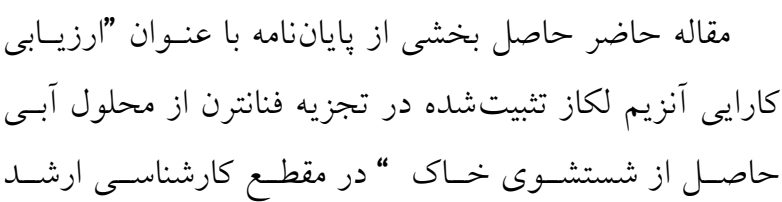

support and excellent activity towards azo dye decolorization. J Environ Chem Eng 2016;4(2):2585-91.

13. Netto CG, Toma HE, Andrade LH. Superparamagnetic nanoparticles as versatile carriers and supporting materials for enzymes. J Mol Catal B 2013;85:71-92.

14. Wang J, Zheng S, Shao Y, et al. Amino-functionalized Fe3O4@ SiO2 core-shell magnetic nanomaterial as a novel adsorbent for aqueous heavy metals removal. J Colloid Interf Sci 2010;349(1):293-9.

15. Mogharabi M, Nassiri-Koopaei N, Bozorgi-Koushalshahi $\mathrm{M}$, et al. Immobilization of laccase in alginate-gelatin mixed gel and decolorization of synthetic dyes. Bioinorg Chem Appl 2012:1-6.

16. Amin R, Khorshidi A, Shojaei AF, et al. Immobilization of laccase on modified Fe3O4@SiO2@ Kit-6 magnetite nanoparticles for enhanced delignification of olive pomace bio-waste. Int J Biol Macromol 2018;114:106-13.

17. Zhang W, Zhang Y, Jiang Q, et al. Tetraazacalix 2 arence 2 triazine coated $\mathrm{Fe} 3 \mathrm{O} 4 / \mathrm{SiO} 2$ magnetic nanoparticles for simultaneous dispersive solid phase extraction and determination of trace multitarget analytes. Anal Chem 2016;88(21):10523-32.

18. Deng M, Zhao H, Zhang S, et al. High catalytic activity of immobilized laccase on core-shell magnetic nanoparticles by dopamine self-polymerization. J Mol Catal B 2015;11:15-24.

19. Azimi M, Nafissi-Varcheh N, Mogharabi M, et al. Study of laccase activity and stability in the presence of ionic and non-ionic surfactants and the bioconversion of indole in laccase-TX-100 system. J Mol Catal Enzym 2016;126:69-75.

20. Hu J, Yuan B, Zhang Y, Guo M. Immobilization of laccase on magnetic silica nanoparticles and its application in the oxidation of guaiacol, a phenolic lignin model compound. RSC Adv 2015;5(120):99439-47.

21. Illanes A. Enzyme biocatalysis: principles and applications: Springer Science \& Business Media; 2008.

22. Bayramoglu G, Doz T, Ozalp VC, Arica MY. Improvement stability and performance of invertase via immobilization on to silanized and polymer brush grafted magnetic nanoparticles. Food Chem 2017;221:1442-50.

23. Xu F. Effects of redox potential and hydroxide inhibition on the $\mathrm{pH}$ activity profile of fungal laccases. J Biol Chem 
1997;272(2):924-8.

24. Zeng S, Qin X, Xia L. Degradation of the herbicide isoproturon by laccase-mediator systems. Biochem Eng J 2017;119:92-100.

25. Niladevi K, Prema P. Effect of inducers and process parameters on laccase production by Streptomyces psammoticus and its application in dye decolourization. Bioresour Technol 2008;99(11):4583-9.

26. Xu R, Cui J, Tang R, et al. Removal of 2, 4, 6trichlorophenol by laccase immobilized on nano-copper incorporated electrospun fibrous membrane-high efficiency, stability and reusability. Chem Eng J 2017;326:647-55.

27. Liu Y, Zeng Z, Zeng G, et al. Immobilization of laccase on magnetic bimodal mesoporous carbon and the application in the removal of phenolic compounds. Bioresour Technol 2012;115:21-6.
28. Jafari AJ, Kalantary RR, Dehghanifard E, et al. Investigation of immobilized laccase enzyme on nanoporous silica application for removal of 2, 4dinitrophenol from aqueous solution. J Mazandaran Univ Med Sci 2017;26(144):301-13.

29. Zdarta J, Antecka K, Frankowski R, et al. The effect of operational parameters on the biodegradation of bisphenols by Trametes versicolor laccase immobilized on Hippospongia communis spongin scaffolds. Sci Total Environ 2018;615:784-95.

30. Kadam AA, Jang J, Lee DS. Supermagnetically tuned halloysite nanotubes functionalized with aminosilane for covalent laccase immobilization. ACS Appl Mater Interfaces 2017;9(18):15492-501.

31. Fortes CC, Daniel-da-Silva AL, Xavier AM, Tavares AP. Optimization of enzyme immobilization on functionalized magnetic nanoparticles for laccase biocatalytic reactions. Chem Eng Process 2017;117:1-8. 